\title{
Standardization method for measurement of hydroxyurea by Ultra High Efficiency Liquid Chromatography in plasma of patients with sickle cell disease
}

\author{
Darcielle Bruna Dias Elias ${ }^{1, *}$, Teresa Maria de Jesus Ponte Carvalho², Janete Eliza de Sá Soares ${ }^{2}$, \\ Romélia Pinheiro Gonçalves ${ }^{2}$
}

\author{
${ }^{1}$ Federal University of Ceará, Fortaleza, CE, Brazil, ${ }^{2}$ Department of Clinical and Toxicological Analysis, Federal University of \\ Ceará, Fortaleza, CE, Brazil
}

\begin{abstract}
Sickle cell anemia (SCA) is a recessively inherited disease characterized by chronic hemolytic anemia, chronic inflammation, and acute episodes of hemolysis. Hydroxyurea (HU) is widely used to increase the levels of fetal hemoglobin $(\mathrm{HbF})$. The objective of this study was to standardize and validate a method for the quantification of $\mathrm{HU}$ in human plasma by using ultra high performance liquid chromatography (UPLC) in order to determine the plasma HU levels in adult patients with SCA who had been treated with HU. We used an analytical reverse phase column (Nucleosil C18) with a mobile phase consisting of acetonitrile/water (16.7/83.3). The retention times of HU, urea, and methylurea were 6.7, 7.7, and $11.4 \mathrm{~min}$, respectively. All parameters of the validation process were defined. To determine the precision and accuracy of quality controls, HU in plasma was used at concentrations of 100,740 , and $1600 \mu \mathrm{M}$, with methylurea as the internal standard. Linearity was assessed in the range of 50-1600 $\mu \mathrm{M} \mathrm{HU}$ in plasma, obtaining a correlation coefficient of 0.99 . The method was accurate and precise and can be used for the quantitative determination of $\mathrm{HU}$ for therapeutic monitoring of patients with SCA treated with HU.
\end{abstract}

Uniterms: Sickle cell anemia/therapeutic monitoring. Hydroxyurea/quantification in human plasma. Ultra High Efficiency Liquid Chromatography/quantitative analysis.

\begin{abstract}
A anemia falciforme (AF) é uma doença hereditária recessiva caracterizada por anemia hemolítica crônica, inflamação crônica e episódios agudos de hemólise. Hidroxiureia (HU) é amplamente utilizada para aumentar os níveis de hemoglobina fetal ( $\mathrm{Hb} \mathrm{F})$. O objetivo consiste em padronizar e validar um método para a quantificação de HU no plasma humano utilizando Cromatografia Líquida de Ultra Alta Eficiência (UPLC), a fim de determinar os níveis de HU em pacientes adultos com AF, tratados com HU. Utilizou-se coluna analítica de fase inversa (Nucleosil C18), fase móvel constituída por acetonitrila/ água $(16,7 / 83,3)$. Os tempos de retenção da HU, uréia e metiluréia foram respectivamente de 6,7, 7,7 e 11,4 minutos. Definiram-se todos os parâmetros do processo de validação. Para determinar a precisão e exatidão dos controles de qualidade utilizaram-se concentrações de 100, 740 e 1600 mM de HU no plasma, empregando como padrão interno a metiluréia. A linearidade foi avaliada no intervalo de 50-1600 mM de HU no plasma, obtendo-se coeficiente de correlação de 0,99 . O método foi considerado exato e preciso e pode ser realizado com o propósito de determinação quantitativa de HU para monitorização terapêutica de pacientes com AF tratados com esse fármaco.
\end{abstract}

Unitermos: Anemia falciforme/monitorização terapêutica. Hidroxiuréia/quantificação em plasma humano. Cromatografia Líquida de Ultra Alta Eficiência/análise quantitativa.

\footnotetext{
*Correspondence: Darcielle Bruna Dias Elias. Rua Conrado Cabral, 384. Ap 203 - Monte Castelo, 60325440 - Fortaleza - Ceará, Brasil. E-mail: darcielle.bruna@gmail.com
} 


\section{INTRODUCTION}

Hydroxyurea (HU), a structural analogue of urea, inhibits the activity of ribonucleotide reductase. It has been used clinically since the 1960 s, primarily in the treatment of Chronic Myeloid Leukemia, acting as a cytotoxic, mutagenic, and recombinogenic antineoplastic agent with specificity to the $\mathrm{S}$ phase of the cell cycle (preventing cell division) and with specific action on ribonucleotide reductase (interfering with the conversion of ribonucleotides to deoxyribonucleotides) (Bachir et al., 2007; Ballas, 2012). Since 1998, HU became part of the therapeutic program for patients with sickle cell anemia (SCA), and was the first drug with proven clinical efficacy in the treatment of this disease. HU is commercially available $\left(\right.$ Hydréia $\left.^{\circledR}\right)$ as a $500 \mathrm{mg}$ tablet and the prescribed dosage ranges from $15-25 \mathrm{mg} / \mathrm{kg} /$ day. Response to HU treatment is variable, since the therapeutic response is associated with the clinical severity of the factors modulating SCA, including the concentration of fetal hemoglobin $(\mathrm{HbF})$ in groups with haplotype beta globin, co-association with alpha-thalassemia, and the presence of polymorphisms for XmnI, BCL11A, and HBS1LMYB (Cokic et al., 2008). Moreover, the variability of the response may be associated with variations in drug metabolism (Cançado et al., 2009).

The efficacy of HU treatment for SCA is generally attributed to its ability to enhance $\mathrm{HbF}$, reducing the intra-erythrocytic polymerization of $\mathrm{HbS}$ in conditions of deoxygenation. However, HU also promotes a reduction in the number of neutrophils, reduced expression of erythrocyte adhesion molecules, and increased synthesis and bioavailability of nitric oxide by the activation of guanylyl cyclase and subsequent increase in cyclic GMP (Friedrisch et al., 2008; Gladwin et al., 2002).

Besides increasing the concentration of $\mathrm{HbF}$, these mechanisms confer benefits such as reduced hemolysis, decreased adhesion of erythrocytes, leukocytes, and platelets to the vascular endothelium, and vasodilatation, contributing to a reduction in vaso-occlusive and inflammatory complications (Lettre et al., 2008).

Despite its proven clinical efficacy, many aspects of the role of $\mathrm{HU}$ in patients with SCA remain unclear, such as optimal therapeutic dose, mechanism of drug action, the intense variability in therapeutic response, and cytotoxicity and genotoxicity. The carcinogenic potential of HU is not well established; some studies associate $\mathrm{HU}$ with an increased risk of leukemia in patients with myeloproliferative disorders (Manouilov, McGuire, Gwilt, 1998; Silva, Shimauti, 2006).

In order to establish a standard treatment regimen based on the pharmacokinetics of HU in patients with SCA, it is necessary to develop and validate a method for the quantification of HU in human plasma. This method was developed based on the methods described by Manouilov et al. (1998) and Bachir et al. (2007). We performed modifications in the sample preparation, using a smaller volume of plasma. For the colorimetric reaction, no commercial kits were used, while an Ultra High Performance Liquid Chromatography with diode detector (UV) was employed as it affords a higher resolution of the chromatograms analyzed. These modifications in the method de Manouilov (1998) and Bachir et al. (2007) resulted in a method with increased sensitivity, lower quantification limit, and reduced time of analysis; nevertheless, its validation is necessary (Manouilov, McGuire, Gwilt, 1998; Bachir et al., 2007).

\section{MATERIAL AND METHODS}

\section{Chemicals}

Hydroxyurea (>98\%; 04/04/2013), methylurea (97\%; 04/04/2013) (internal standart), diacetyl monoxime $\left(\mathrm{C}_{4} \mathrm{H}_{7} \mathrm{NO}_{2}\right)$, tiosemicarbazide $\left(\mathrm{CH}_{5} \mathrm{~N}_{3} \mathrm{~S}\right)$ and ferric chloride $\left(\mathrm{FeCl}_{3}\right)$ were purchased from SIGMA ${ }^{\circledR}$ (St. Louis, MO, USA). Sodium chloride $(\mathrm{NaCl})$ from LABSYNTH ${ }^{\circledR}$ (SP, Brazil) sulfuric acid from Cromato Produtos Químicos Ltda (SP, Brazil), orthophosporic acid from TEDIA ${ }^{\circledR}$ (RJ, Brazil), trichloroacetic acid and acetonitrile were purchased from VETEC ${ }^{\circledR}$ (RJ, Brazil). Plasma standards were obtained from Hemocenter of the State of Ceará, Brazil.

\section{Solutions}

A stock solution of hydroxyurea was prepared in acetonitrile/water (1:1) at a concentration of $10,000 \mu \mathrm{M}$, which was dissolved in acetonitrile/water (1:1) to obtain concentrations of $8000,6000,3200,2000,1000,500$, and $250 \mu \mathrm{M}$. The standard solutions were stored in a $4{ }^{\circ} \mathrm{C}$, and after comparison with the test solutions prepared freshly observed stable for 20 days. The methylurea solution used as internal standard was prepared at a concentration of $15.5 \mathrm{mM}$.

The colorimetric solution (A) was prepared by combining $0.2 \mathrm{~g}$ thiosemicarbazide, $0.9 \mathrm{~g}$ sodium chloride, and $0.1 \mathrm{~g}$ diacetyl monoxime in distilled water qsp $100 \mathrm{~mL}$. The acid solution (B) was prepared by adding $6 \mathrm{~mL}$ sulfuric acid $\left(\mathrm{H}_{2} \mathrm{SO}_{4}\right)$ and $1 \mathrm{~mL}$ phosphoric acid to $80 \mathrm{~mL}$ of distilled water, dissolving $0.01 \mathrm{~g}$ ferric chloride in this solution, and filling to $100 \mathrm{~mL}$ with distilled water. 


\section{Chromatographic conditions}

The equipment Ultra High Performance Liquid Chromatography (UPLC) consists of a pumping system with diode array detector (PDA) (Accela ${ }^{\circledR}$ Thermo Scientific) and data acquisition system ChromQuest 5.0 (Thermo Scientific $^{\circledR}$ ). Compounds were separated by reverse-phase chromatography on analytical column NUCLEOSIL C18, 250_4.6 column (5 $\mu$ m particle size) from Phenomenex ${ }^{\circledR}$ and pre-column C18 (4x30 mm). The mobile phase used was acetonitrile/water (16.7 / 83.3) flow of $1 \mathrm{~mL} / \mathrm{min}$, wavelength $440 \mathrm{~nm}$.

\section{Sample preparation}

In a $10 \mathrm{~mL}$ tube, $400 \mu \mathrm{L}$ aliquots of plasma from patients treated with hydroxyurea were combined with $80 \mu \mathrm{L}$ of $15.5 \mathrm{mM}$ methylurea (internal standard) and $800 \mu \mathrm{L}$ of $20 \%$ trichloroacetic acid to precipitate proteins. After vortexing (30 s) and centrifugation (3500 rpm for $10 \mathrm{~min}), 1000 \mu \mathrm{L}$ of supernatant were transferred to another tube, and $1000 \mu \mathrm{L}$ of solution A(colorimetric) and $1000 \mu \mathrm{L}$ of solution B (acid reagent) were added. The mixture was heated in a water bath to $100^{\circ} \mathrm{C}$ for $10 \mathrm{~min}$ and then cooled to $4{ }^{\circ} \mathrm{C}$ for $10 \mathrm{~min}$. A $25 \mu \mathrm{L}$ sample of the reaction product was subjected to chromatographic analysis.

\section{Calibration curve}

To construct the calibration curve (performed in triplicate), $400 \mu \mathrm{L}$ aliquots of human plasma blanks (those not treated with hydroxyurea) were enriched with $100 \mu \mathrm{L}$ of an appropriate concentration of the working standard solution to obtain hydroxyurea concentrations of 50, $100200,400,740,1200$, and $1600 \mu \mathrm{M}$ in plasma; these concentrations were chosen based on the expected plasma levels of HU and comprised seven data points, including the quantification limit. The internal standard $(80 \mu \mathrm{L}, 15.5 \mathrm{mM})$ was added to each solution, which was then subjected to the process of sample preparation and chromatographic analysis as described above.

The linear regression equations and correlation coefficients were obtained by dividing the peak area of hydroxyurea by the area of the internal standard (hydroxyurea/IS), plotted as a function of their concentrations. The acceptance criteria for calibration curves included a linear correlation coefficient greater than or equal to 0.99 , a deviation less than or equal to $20 \%$ compared to the nominal concentration for the lower limit of quantification, and a standard deviation less than or equal to $15 \%$ over nominal concentration for the other concentrations of the calibration curves.

\section{Validation}

The validation process was performed in October 2012 in accordance with Resolution RDC no 27 of $17 / 05 / 2012$, the Ministry of Health - National Health Surveillance Agency, which is also in accordance with the Guidance for Industry - Bioanalytical Method Validation, 2013. (Brazil, 2012; FDA, 2013)

\section{Limit of quantification}

The limit of quantification was defined as the lowest concentration quantified with precision and accuracy with relative standard deviation (RSD) and coefficient of variation $(\mathrm{CV} \%) \pm 20 \%$. Samples of human plasma were enriched with hydroxyurea to yield concentrations as low as $50 \mu \mathrm{M}$. The samples were analyzed in quintuplicate.

\section{Linearity}

Linearity was assessed at the concentrations used in the calibration curve, by gradually increasing the concentration to $1600 \mu \mathrm{M}$ hydroxyurea in plasma. After. we determined the linear regression equations and correlation coefficients.

\section{Selectivity}

The interference from endogenous components of plasma was assessed by the analysis of plasma aliquots obtained from six different individuals who were not treated with hydroxyurea.

\section{Precision and accuracy}

To determine precision and accuracy, quality controls were used at concentrations of 100,740 , and $1600 \mu \mathrm{M}$ of hydroxyurea in plasma.

To evaluate precision within assays, 5 aliquots were analyzed for each control on a single day, or across a single calibration curve. To evaluate the precision between assays, aliquots were analyzed in quintuplicate, with quality controls on three consecutive days. Precision was expressed as coefficient of variation (CV\%), assuming no values of $\pm 15 \%$ (fifteen percent).

Accuracy within and between assays was also evaluated using the experimental results from the precision evaluations. The accuracy was expressed through the Relative Standard Error (RSE), not including values 
outside the range of $\pm 15 \%$ (fifteen percent) of the nominal value.

$\mathrm{RSE}=\frac{\text { Average concentration experimental }- \text { nominal value }}{\text { nominal value }} \times 100$

\section{Clinical and experimental protocol}

We analyzed 22 adult patients ( 5 men and 17 women, aged between 20 and 40 years) with clinical and laboratory diagnoses of SCA, confirmed by molecular biology, with a baseline treatment with hydroxyurea for over a year, accompanied at the outpatient clinic of a university hospital in Fortaleza, Ceará, Brazil. Baseline determination was based on the criteria described by Ballas (2012): absence of painful episodes and/or concurrent illnesses such as infections or inflammation in the four weeks preceding the study; no hospital admissions in the 2-3 days prior to study; and absence of blood transfusion in the four months preceding the study. The exclusion criteria included an absence of molecular diagnosis of SCA, pregnancy, presence of renal or liver failure, or smoking (Ballas, 2012).

Informed consent was obtained from all patients (or from the responsible person) prior to enrollment into the study, and the study protocol was submitted to and approved by the Ceará Federal University Ethics Committee under protocol $\mathrm{N}^{\circ} 110.10 .10$.

Venous blood was collected in containers containing the anticoagulant heparin, $2.5 \mathrm{~h}$ after drug intake. Plasma samples for chromatographic analysis were obtained by centrifugation of the blood samples at $4000 \mathrm{rpm}$ for 10 min and were stored at $-80^{\circ} \mathrm{C}$ until the time of analysis.

Plasma concentrations of hydroxyurea in the patients tested was calculated using the calibration curves.

\section{RESULTS}

\section{Analysis of hydroxyurea in plasma}

Figures 1 and 2 show the chromatographic analysis of a plasma blank enriched with solutions of hydroxyurea and methylurea (internal standard) and plasma from a patient with sickle cell disease being treated with hydroxyurea (1000 mg/day), respectively. It was observed that the retention times of hydroxyurea, urea, and methylurea were $6.763 \mathrm{~min}, 7.778 \mathrm{~min}$, and $11.472 \mathrm{~min}$, respectively.

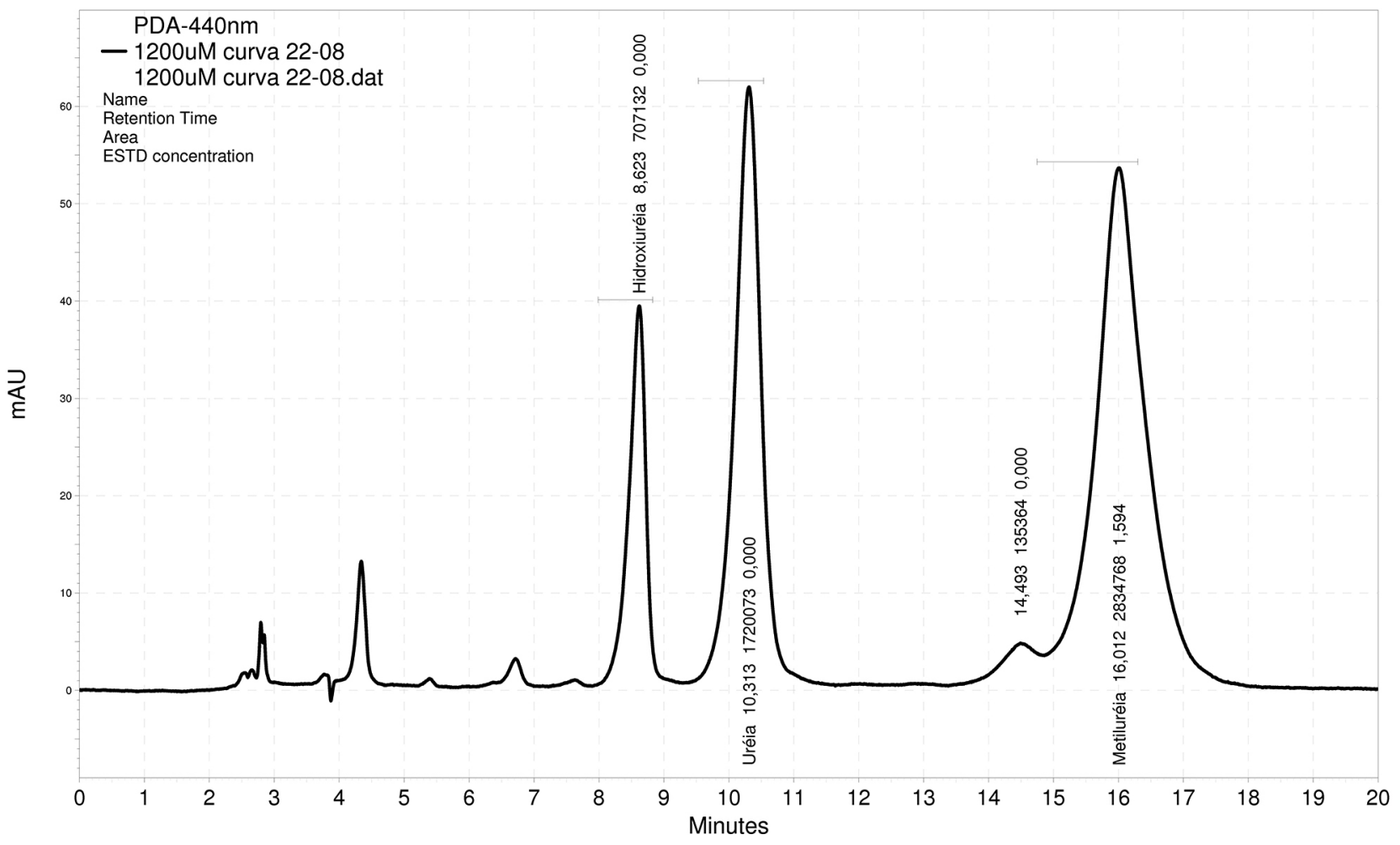

— C:IChromQuest|EnterpriselProjects\Default|Datal1200uM curva 22-08.dat, PDA-440nm

FIGURE 1 - Chromatogram of plasma enriched with $1200 \mu \mathrm{M}$ hydroxyurea and $15.5 \mathrm{mM}$ methylurea (internal standard). 


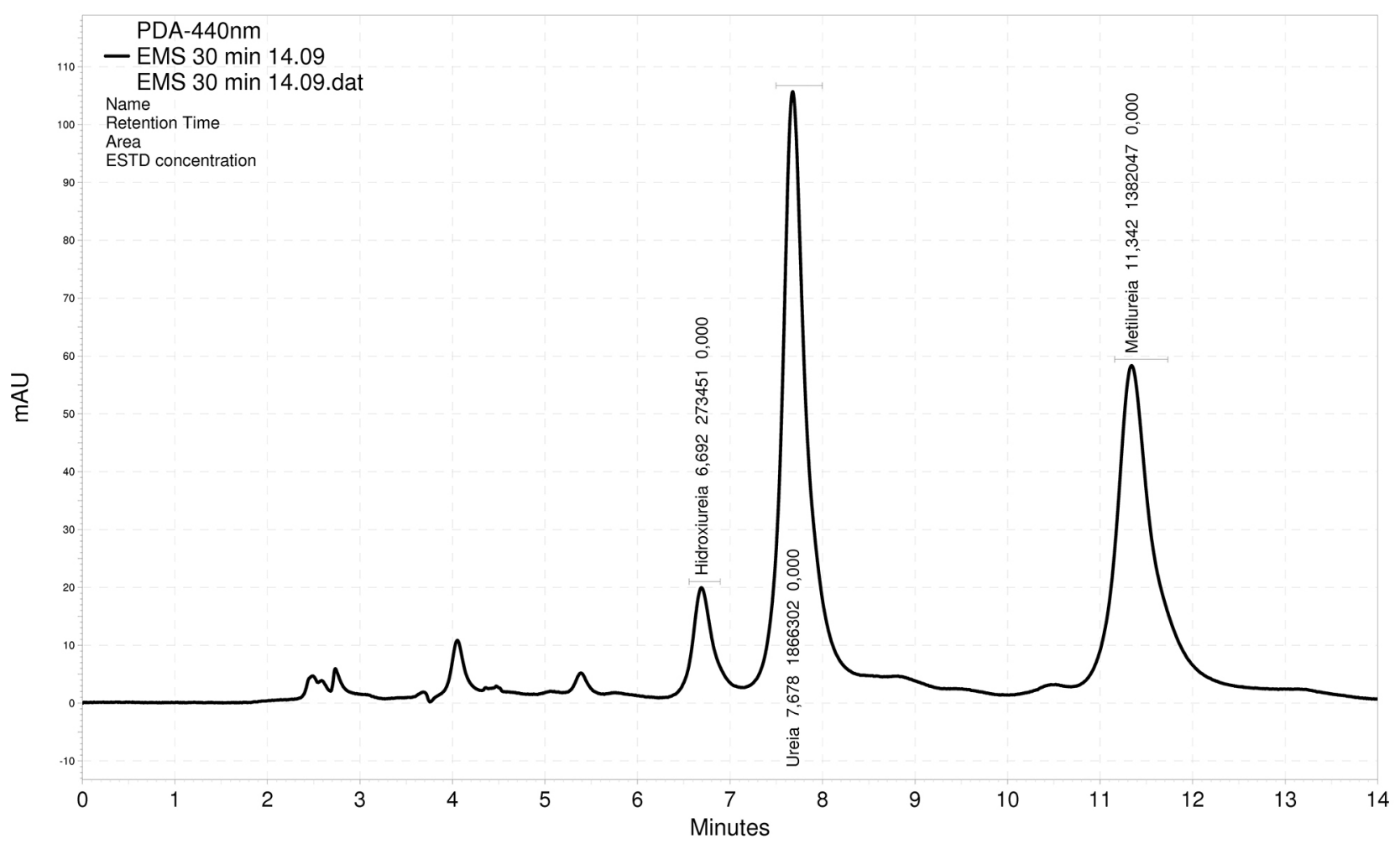

C C:IChromQuest|EnterpriselProjects|Default|DatalEMS 30 min 14.09.dat, PDA-440nm

FIGURE 2 - Chromatogram of plasma from patients undergoing SCA therapy with hydroxyurea $1000 \mathrm{mg} /$ day enriched with $15.5 \mathrm{mM}$ methylurea (internal standard).

\section{Calibration Curve}

The Figure 3 shows the calibration curve in the range of 50-1600 $\mathrm{mM}$ of hydroxyurea in human plasma. The correlation coefficient was 0.9908 .

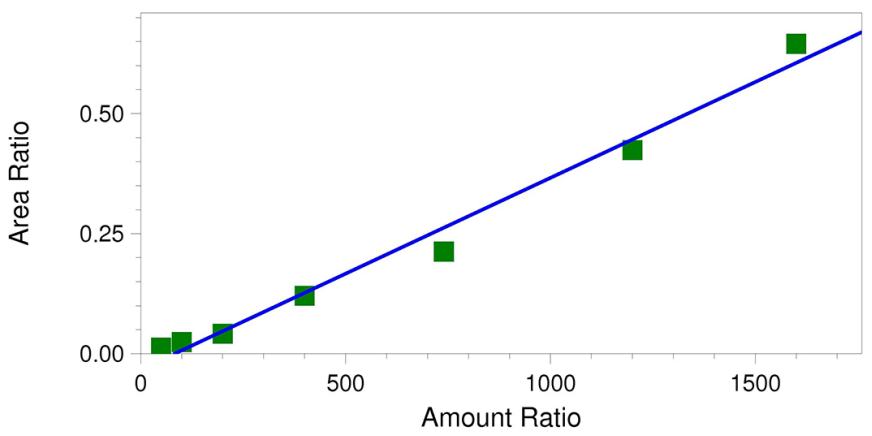

FIGURE 3 - Calibration curve of HU in the range of 50-1600 $\mu \mathrm{M}$ hydroxyurea in human plasma.

\section{Validation of method}

Table I shows the results of the validation of the analytical method of hydroxyurea in human plasma. The calculated correlation coefficient (r) indicates a linear relationship between the area and the concentration of hydroxyurea. Method was validated according to national guidelines for the validation of analytical and bioanalytical methods (RDC 27/2012) and to the ICH (International Conference on Harmonisation) guidelines for bioanalytical method validation (ANVISA, 2012; International Conference on Harmonisation, 2001).

\section{Analysis of patients}

We analyzed 22 adult patients ( 5 men and 17 women, aged between 20 and 40 years) with clinical and laboratory diagnoses of SCA treated with hydroxyurea for over one year, at doses of $500 \mathrm{mg} /$ day (1 patient), $1000 \mathrm{mg} /$ day (18 patients), and $1500 \mathrm{mg} /$ day (3 patients), and the average $\mathrm{HU}$ concentrations in plasma collected from these dosage groups were $98.31 \mu \mathrm{M}, 190.88 \mu \mathrm{M}$, and $302.71 \mu \mathrm{M}$, respectively.

\section{DISCUSSION}

Hydroxyurea therapy in patients with sickle cell 
TABLE I - Confidence limits for the method of analysis of hydroxyurea

\begin{tabular}{lc}
\hline & Hydroxyurea \\
\hline Linearity $(50-1600 \mu \mathrm{M})$ & \\
Line Equation & $\mathrm{y}=0.00029 \mathrm{x}-0.00285$ \\
$\mathrm{R}$ & 0.99084 \\
\hline Limit of Quantification $(50 \mu \mathrm{M})$ & \\
Precision $(\mathrm{CV} \%, \mathrm{n}=5)$ & 13.45 \\
Accuracy $(\mathrm{RSE}, \mathrm{n}=5)$ & 4.96 \\
\hline Precision within assays & \\
$(\mathrm{CV} \%, \mathrm{n}=5)$ & \\
$100 \mu \mathrm{M}$ & 2.22 \\
$740 \mu \mathrm{M}$ & 2.52 \\
$1200 \mu \mathrm{M}$ & 4.52 \\
\hline
\end{tabular}

\begin{tabular}{lc}
\hline Precision between assays & \\
$(\mathrm{CV} \%, \mathrm{n}=15)$ & \\
$100 \mu \mathrm{M}$ & 6.39 \\
$740 \mu \mathrm{M}$ & 7.04 \\
$1200 \mu \mathrm{M}$ & 10.38 \\
\hline
\end{tabular}

\begin{tabular}{lc}
\hline Accuracy within assays & \\
$(\mathrm{RSE} \%, \mathrm{n}=5)$ & \\
$100 \mu \mathrm{M}$ & 0.80 \\
$740 \mu \mathrm{M}$ & -4.26 \\
$1200 \mu \mathrm{M}$ & -5.94 \\
\hline
\end{tabular}

Accuracy between assays

$(\mathrm{RSE} \%, \mathrm{n}=15)$

$100 \mu \mathrm{M} \quad-1.35$

$740 \mu \mathrm{M} \quad-2.50$

$1200 \mu \mathrm{M}$

$\mathrm{CV}=$ Coefficient of variation [(SD/média)x 100];

$\mathrm{r}=$ linear correlation coefficient.

$\mathrm{RSE}=[($ Caverage experimental-C added $) / \mathrm{C}$ added $] \times 100$

TABLE 2 - Average concentrations of HU in patients with SCA

\begin{tabular}{lcc}
\hline $\begin{array}{l}\text { Treatment dose } \\
(\mathrm{mg} / \text { day })\end{array}$ & $\begin{array}{c}\text { Average } \\
\text { Concentration } \\
(\mu \mathrm{M}) \pm \mathrm{SD}\end{array}$ & $\mathrm{N}$ \\
\hline 500 & $98,31 \pm 0$ & 1 \\
1000 & $190,88 \pm 100,7433$ & 3 \\
1500 & $302,71 \pm 212,6223$ & 18 \\
\hline
\end{tabular}

anemia (SCA) has a proven clinical and laboratory efficacy. Administered in concentrations of 15 to $25 \mathrm{mg} / \mathrm{kg} /$ day, it can induce an increase of 10 to $40 \%$ of $\mathrm{HbF}$. However, the variability in therapeutic response is high and may be associated with pharmacogenetic factors that lead to phenotypic characteristics of fast or slow metabolizers. Given this variation, the search for a safe therapeutic use that avoids the cyto- and genotoxicity of the drug through a standard regimen based on therapeutic monitoring is essential (Steinberg et al., 2010; Veale et al., 1988). Thus, the quantification method of hydroxyurea in human plasma by UPLC with diode detector (UV) was developed in order to follow up patients treated with this drug. It was developed from the methods of Manouilov et al. (1998) and Bachir et al. (2007) and is based on the formation of a color reaction between hydroxyurea and solutions A (thiosemicarbazide + sodium chloride + diacetyl monoxime) and $\mathrm{B}$ (sulfuric acid + phosphoric acid + ferric chloride) (Manouilov, McGuire, Gwilt et al., 1998; Bachir et al., 2007).

While developing the method, the optimal wavelength was chosen by performing a "scan" of wavelengths between 300 and $600 \mathrm{~nm}$. A wavelength of $440 \mathrm{~nm}$ was identified as having the highest absorption. To choose the best mobile phase, adjustments were made in the proportions of acetonitrile/water, and the analysis time obtained was of $13 \mathrm{~min}$, a reduction of $50 \%$ compared to the method of Bachir et al. (2007), which used 16.7\% acetonitrile (Bachir et al., 2007).

The plasma sample was treated by an initial precipitation of proteins (clean-up) using trichloroacetic acid instead of perchloric acid, as described by Bachir et $a l$. and Manouilov et al., thereby reducing interference by endogenous substances. After this step, the colorimetric reaction was carried out (Manouilov, McGuire, Gwilt, 1998; Bachir et al., 2007).

The specificity of the method was confirmed when it was observed that the retention times of hydroxyurea, urea, and methylurea were $6.763 \mathrm{~min}, 7.778 \mathrm{~min}$, and $11.472 \mathrm{~min}$, respectively, with no interference to methylurea (internal standard) or urea from endogenous substances at high concentrations in the plasma. The calibration curve in the concentration range of 50-1600 $\mu \mathrm{M}$ hydroxyurea in plasma was selected from therapeutic concentrations observed in the dosages of $15 \mathrm{mg} / \mathrm{kg} /$ day to $30 \mathrm{mg} / \mathrm{kg} /$ day of hydroxyurea.

The calibration curve in the concentration range of 50-1600 $\mu \mathrm{M}$ hydroxyurea in plasma was selected from therapeutic concentrations observed in the dosages of $15 \mathrm{mg} / \mathrm{kg} /$ day to $30 \mathrm{mg} / \mathrm{kg}$ /day of hydroxyurea.

The method was deemed precise and accurate, using quality controls at low, middle, and high concentrations of $100 \mu \mathrm{M}, 740 \mu \mathrm{M}$, and $1200 \mu \mathrm{M}$, respectively, presenting a quantification limit, selectivity, precision, and accuracy compatible with application in the analysis of hydroxyurea in patients treated with a multiple dose regimen. Moreover, the method was considered to be linear, since the obtained correlation coefficient was greater than 0.99 .

We note that, in the validation process, hydroxyurea, 
methylurea standard solution, and solutions A and B used in colorimetric reaction all showed a stability of greater than 20 days. The color reaction product was unstable after $5 \mathrm{~h}$ of reaction, with a decrease in absorbance, and plasma samples containing hydroxyurea are unstable for a period longer than six months even when stored at $-80^{\circ} \mathrm{C}$.

The mean concentrations obtained $2.5 \mathrm{~h}$ after ingestion of hydroxyurea in doses of $500 \mathrm{mg}, 1000 \mathrm{mg}$, and $1500 \mathrm{mg}$ per day were $98.31,190.88$, and $302.71 \mu \mathrm{M}$, respectively, compatible with the pharmacokinetics of the drug, whose maximum concentration (Cmax) is $793.75 \mu \mathrm{M}$ for a dose of $2000 \mathrm{mg} /$ day with maximum time (Tmax) of $1.22 \mathrm{~h}$ (Ware et al., 2011; Rodriguez et al., 1998). However, it should be noted that there are phenotypic differences in drug metabolism; in rapid metabolizers, Cmax is achieved 15 to 30 min after ingestion, whereas in poor metabolizers Cmax is achieved 60 to $120 \mathrm{~min}$ after ingestion (Ware et al., 2011; Rodriguez et al., 1998). Therefore, for therapeutic monitoring of patients treated with HU, the ideal collection time would be $30 \mathrm{~min}$ and $1.5 \mathrm{~h}$ after drug intake.

The results of this study demonstrate that the method presents highly linear correlation and can be used for quantitative determination of hydroxyurea for therapeutic monitoring in patients with sickle cell anemia.

\section{ACKNOWLEDGMENTS}

Financial support for this study was provided by the National Council of Technological and Scientific Development - (CNPq - Brazil).

\section{REFERENCES}

BACHIR, D.; HULlin, A.; HUET, E.; ANOOSHA, H.; NZOUAKOU, R.; EL MADJELINE, M.; ASTIER, A.; GALACTEROS, F. Plasma and urine hydroxyurea levels might be useful in the management of adult sickle cell disease. Hemoglobin, v.31, n.4, p.417-425, 2007.

BALLAS, S.K. More definitions in sickle cell disease: steady state v base line data. Am. J. Hematol., v.87, n.3, p.338, 2012 .

BRASIL. Agência Nacional de Vigilância Sanitária. ANVISA. Resolução n.27, de 17 de maio de 2012. Guia para validação de métodos analíticos e bioanalíticos. Diário Oficial da União. Poder Executivo, Brasília DF, 17 de maio de 2012. Available at: http://www.anvisa.gov.br/e-legis/. Accessed on: 04 Apr. 2014.
COKIC, V.P.; ANDRIC, S.A.; STOJIKOVIC, S.S.; NOGUCHI, C.T.; SCHECHTER, A.N. Hydroxyurea nitrosylates and activates soluble guanylyl cyclase in human erythroid cells. Blood, v.111, n.3, p.1117-1123, 2008.

CANÇADO, R.D.; LOBO, C.; ÂNGULO, I.L.; ARAÚJO, P.I.C.; JESUS, J.A. Protocolos clínico e diretrizes terapêuticas para uso de hidroxiureia na doença falciforme. Rev. Bras. Hematol. Hemoter., v.31, n.5, p.361-366, 2009.

FRIEDRISCH, J.R.; PRA, D.; MALUF, S.W.; BITTAR, C.M.; MERGENER, M.; POLLO, T.; KAYSER, M.; SILVA, M.A.L.; HENRIQUES, J.A.P.; SILLA, L.M.R. DNA damage in blood leukocytes of individuals with sickle cell disease treated with hydroxyurea. Mutat. Res., v.649, n.1-2, p.213-220, 2008.

FOOD AND DRUG ADMINISTRATION. Guidance for industry: bioanalytical method validation. Rockville: FDA, 2013. $20 \mathrm{p}$.

INTERNATIONAL Conference on Harmonisation. ICH. Guidance for industry: bioanalytical method validation. ICH, 2001. Available at: <http://www.ich.org/>. Accessed on: 4 Apr. 2014.

GLADWIN, M.T.; SHELHAMER, J.H.; OGNIBENE, F.P.; PEASE-FYE, M.E.; NICHOLS, J.S.; LINK, B.; PATEL, D.B.; JANKOWSKI, M.A.; PANNELL, L.K.; SCHECHTER, A.N.; RODGERS, G.P. Nitric oxide donor properties of hydroxyurea in patients with sickle cell disease. Br. J. Haematol. v.116, n.2, p.436-444, 2002.

LETTRE, G.; SANKARAN, V.G.; BEZERRA, M.A.; ARAÚJO, A.S.; UDA, M.; SANNA, S.; CAO, A.; SCHLESSINGER, D.; COSTA, F.F.; HIRSCHHORN, J.N.; ORKIN, S.H. DNA Polymorphisms at the BCL11A, HBS1L-MYB, and beta globin loci associate with fetal hemoglobin levels and pain crises in sickle cell disease. Proc. Natl. Acad. Sci. USA, v.105, n.33, p.11869-11874, 2008.

MANOUILOV, K.K.; MCGUIRE, T.R.; GWILT, P.R. Colorimetric determination of hydroxyurea in human serum using high-performance liquid chromatography. $J$. Chromatogr. B. Biomed. Sci. Appl., v.708, n.1-2, p.321324, 1998.

SILVA, M.C.; SHIMAUTI, E.L.T. Eficácia e toxicidade da hidroxiureia em crianças com anemia falciforme. Rev. Bras. Hematol. Hemoter., v.28, n.2, p.144-114, 2006. 
STEINBERG, M.H.; McCARTHY, W.F.; CASTRO, O.; BALLAS, S.K.; ARMSTRONG, F.D.; SMITH, W.; ATAGA, K.; SWERDLOW, P.; KUTLAR, A.; DeCASTRO, L.; WACLARWIN, M.A. The risks and benefits of longterm use of hydroxyurea in sickle cell anemia: a 17.5 year follow-up. Am. J. Hematol., v.85, n.6, p.403-408, 2010.

VEALE, D.; CANTWELL, B.M.J.; KERR, N.; UPFOLD, A.; HARRIS, A.L. Phase I study of hydroxyurea in lung cancer. Cancer Chemother. Pharm., v.21, n.1, p.53-56, 1988.

WARE, R.E.; DESPOTOVIC, J.M.; MORTIER, N.A.; FLANAGAN, J.M.; HE, J.; SMELTZER, M.P.; KIMBE, A.C.; AYGUN, B.; WU, S.; HOWARD, T.; SPARREBOOM, A. Pharmacokinetics, pharmacodynamics, and pharmacogenetics of hydroxyurea treatment for children with sickle cell anemia. Blood, v.118, n.3, p.49854991, 2011.
RODRIGUEZ, G.I.; KUHN, J.G.; WEISS, G.R.; HILSENBECK, S.G.; ECKARDT, J.R.; THURMAN, A.; RINALDI, D.A.; HODGES, S.; VON HOFF, D.D.; ROWINSKY, E.K. A bioavailability and pharmacokinetic study of oral and intravenous hydroxyurea. Blood, v.91, n.5, p.1533-1541, 1998.

Received for publication on $30^{\text {th }}$ September 2013 Accepted for publication on $08^{\text {th }}$ May 2014 